\title{
Studi Potensi Kawasan Subak Sebagai Ekowisata di Desa Belimbing Kecamatan Pupuan Kabupaten Tabanan
}

\author{
DEWA AYU BULAN INDRAYUNI ${ }^{1}$, NANIEK KOHDRATA ${ }^{2 *}$ \\ I MADE SUKEWIJAYA ${ }^{1}$
}

\begin{abstract}
1. Program Studi Agroekoteknologi, Fakultas Pertanian, Universitas Udayana
Jl. PB. Sudirman-Denpasar, 80362, Indonesia
\end{abstract}

2. Program Studi Arsitektur Pertamanan, Fakultas Pertanian, Universitas Udayana, Jl. PB. Sudirman-Denpasar, 80362, Indonesia

*E-mail: naniek_kohdrata@unud.ac.id

\section{ABSTRACT \\ Potential Study of Subak Area for Ecotourism in Belimbing Village, Pupuan District, Tabanan Regency}

Tabanan regency is the highest rice producing regency in Bali. The survess in agricultural production is inseparable from Subak organization existency. This past few years, Tabanan experiencing an increase land conversion. It becomes a threat to the existence of Subak. Developing ecotourism in Subak area is an effort to reduce numbers of land conversion and Subak degradation. Belimbing village has a potential to be developed as ecotourism. The potential identification in Subak area of the village shows there are some Subak values as well as environment potentials that can be developed as area for ecotourism. The beautiful landscape of rice field terrace, Tri Hita Karana (THK) based agricultural and local community social cultured activities are potential for tourist attraction. However, there is a need to educate the local people in order to support the implementation of ecotourism in Subak area of Belimbing village. By developing Subak area as ecotourism, it is expected to improve the welfare of the local people, especially former and Subak organization also preserve the environment as well.

Keywords: ecotourism, identification of potential, subak areas

\section{Pendahuluan}

Kabupaten Tabanan merupakan salah satu kabupaten di Bali yang memiliki peran sentral dalam pertanian. Kabupaten Tabanan memiliki julukan "lumbung beras" Provinsi Bali. Menurut data Badan Pusat Statistik (BPS) Provinsi Bali tahun 2015, luas sawah di Kabupaten Tabanan sebesar 21.962 ha dari total 80.542 ha sawah di Bali. Ditinjau dari produksi padi sawah, Kabupaten Tabanan selalu menempati posisi tertinggi. Tahun 2014 Kabupaten Tabanan dapat menghasilkan gabah 214.192 ton dari total produksi padi sawah di Provinsi Bali 857.499 ton. Dari total luas lahan persawahan yang ada di 
Kabupaten Tabanan, Kecamatan Pupuan memiliki luas lahan persawahan tertinggi di Kabupaten Tabanan dibandingkan kecamatan lainnya. Dengan luas wilayah 179,02 km², sebagian besar wilayah Kecamatan Pupuan merupakan lahan pertanian dan perkebunan.

Seiring bertambahnya jumlah penduduk, angka konversi lahan dari lahan pertanian ke nonpertanian kian meningkat. Hal tersebut dapat memberikan dampak yang signifikan terhadap produksi pangan, aspek sosial budaya, aspek sosial ekonomi, dan juga aspek lingkungan. Menurut BPS Bali tahun 2013 (BPS Bali, 2014), angka konversi lahan dari sektor pertanian ke nonpertanian di Kabupaten Tabanan selama tahun 2012 - 2013 mencapai 204 ha. Pada tahun 2012, luas lahan sawah mencapai 22.388 ha, sedangkan tahun 2013 menyusut menjadi 22.184 ha. Berdasarkan data dari BPS Bali 2014 (BPS Bali, 2015), pada tahun 2014 terjadi penyusutan luas lahan sawah sebesar 222 ha. Angka tersebut mungkin akan terus bertambah apabila tidak ditanggulangi dengan cepat dan tepat.

Disamping permasalahan di atas, permasalahan lainnya adalah sulitnya mendapatkan air irigasi yang cukup. Hal tersebut biasanya disebabkan oleh pengalokasian jumlah air yang lebih banyak ke sektor nonpertanian dan minimnya sumber air untuk irigasi. Meskipun demikian, lahan persawahan di Kecamatan Pupuan tidak menemui kendala tersebut karena dapat teraliri dengan air yang cukup. Hal ini tidak lepas dari peran organisasi subak yang ada. Salah satu dampak dari meningkatnya konversi lahan di Kabupaten Tabanan adalah terkikisnya eksistensi subak. Padahal, subak merupakan salah satu pilar kebudayaan Bali yang sangat penting dijaga kelestariannya.

Bali merupakan salah satu tempat tujuan wisata budaya, di mana budaya yang dimiliki Bali menjadi daya tarik utama bagi para wisatawan. Jika keberadaan subak tidak dapat dipertahankan, eksistensi sektor pariwisata di Bali juga akan terkena imbasnya. Apabila suatu organisasi subak yang dalam setiap kegiatannya berlandaskan harmoni dan kebersamaan yang sarat dengan nilai budaya, lambat laun mulai menghilang tergerus arus globalisasi, maka salah satu pilar kebudayaan Bali juga akan menghilang. Jika hal tersebut menghilang, maka daya tarik yang dimiliki Bali juga akan menghilang dan berdampak pada sektor pariwisata dan sosial ekonomi masyarakat Bali.

Untuk mencegah terjadinya konversi lahan yang berimbas pada eksistensi subakadalah mencarikan alternatif pengembangan kawasan subak sebagai upaya menjaga eksistensi subak. Salah satu caranya adalah dengan menjadikan kawasan subak sebagai salah satu alternatif tujuan wisata. Salah satu desa di Kecamatan Pupuan Kabupaten Tabanan memiliki potensi wisata yang dapat dinikmati seperti halnya Jatiluwih maupun Ceking. Kawasan subak di Desa Belimbing, Kecamatan Pupuan, Kabupaten Tabanan memiliki daya tarik tersendiri untuk dikembangkan sebagai kawasan wisata subak.

Agar pengembangan kawasan subak di Desa Belimbing dapat sesuai dengan potensi yang dimilikinya, maka diperlukan studi mengenai potensi-potensi yang ada di kawasan subak yang dapat mendukung pengembangan kawasan subak sebagai ekowisata. Tujuan penelitian ini adalah untuk mengidentifikasi potensi yang dimiliki 
kawasan subak di Desa Belimbing, sehingga dapat memberikan rekomendasi pengembangan kawasan subak sebagai ekowisata berdasarkan potensi yang dimilikinya.

\section{Metode}

Data yang dikumpulkan dalam penelitian studi potensi ini berupa data primer dan data sekunder. Metode yang digunakan dalam penelitian ini adalah metode survey. Tahapan penelitian mencakup pengumpulan data yang dilakukan dengan survey lapang, wawancara, dan studi pustaka. Tahap berikutnya yaitu analisis untuk mempelajari keterkaitan aspek-aspek yang dinilai berdasarkan data-data yang telah diperoleh. Teknik analisis menggunakan 6 kerangka kerja untuk menganalisis destinasi pariwisata menurut Buhalis. Menurut Buhalis (2000), ada 6A yang dapat digunakan untuk menganalisis destinasi pariwisata, yaitu: attractions, accessibility, amenities, available packages, activity, dan ancillary services.

\section{Hasil dan Pembahasan}

Desa Belimbing merupakan salah satu dari 14 desa yang berada di Kecamatan Pupuan, Kabupaten Tabanan. Desa Belimbing memiliki luas sekitar 22,49 $\mathrm{km}^{2}$ atau $12,56 \%$ dari luas Kecamatan Pupuan atau 2,68\% dari luas Kabupaten Tabanan (Kecamatan Pupuan Dalam Angka, 2014). Dari luas wilayah 2.606,66 ha, 370 ha (14,19\%) merupakan wilayah persawahan, 1700,56 ha $(65,23 \%)$ merupakan wilayah perkebunan, dan sisanya digunakan untuk sektor non-pertanian. Jika dilihat dari penggunaan lahannya, sebagian besar lahan digunakan untuk pertanian, baik itu lahan basah maupun lahan kering. Hal ini dapat mendukung jika Desa Belimbing dikembangkan sebagai ekowisata, karena banyak wilayah yang dapat dieksplorasi untuk menjadi daya tarik wisatawan yang ingin menikmati ekowisata di Desa Belimbing.

Rata-rata suhu tahunan di Desa Belimbing adalah $21^{\circ} \mathrm{C}$. Dengan suhu terendah terjadi pada bulan Januari, yaitu $20^{\circ} \mathrm{C}$ dan suhu tertinggi terjadi di bulan Agustus, yaitu $30^{\circ} \mathrm{C}$ (Kecamatan Pupuan Dalam Angka, 2014). Hal ini menunjukkan bahwa, suhu pada tapak cukup sejuk sehingga dapat memberikan kenyamanan bagi masyarakat maupun wisatawan.

Desa Belimbing terletak pada ketinggian 500 - $1000 \mathrm{~m}$ di atas permukaan laut (dpl). Iklim di Desa Belimbing tergolong iklim tropis sama halnya dengan wilayah di Pulau Bali lainnya. Musim kemarau biasanya terjadi pada bulan April - Oktober dan musim hujan terjadi pada bulan November - Maret. Keadaan iklim ini berpengaruh terhadap penentuan musim tanam oleh subak-subak yang ada. 


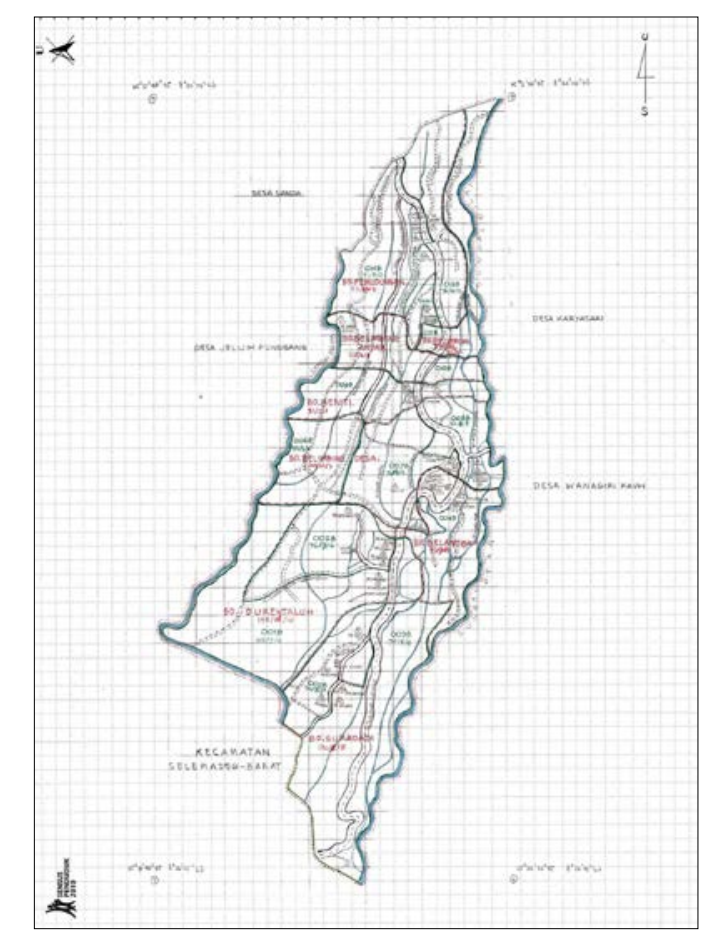

Gambar 1. Peta Desa Belimbing (BPS Tabanan, 2010)

Berdasarkan Tabel 1, musim tanam di Desa Belimbing biasanya dilakukan sekitar bulan Februari dan Agustus dengan komoditas utama pada pertanian lahan basah adalah padi. Wisatawan dapat melakukan kunjungan sepanjang tahun, pada bulan Januari Februari dan bulan Juli - Agustus, pengunjung akan disuguhi pemandangan persawahan yang hanya tergenangi air saja tanpa ada tanaman padi karena sedang dalam masa bera, namun wisatawan masih dapat menikmati atraksi berupa petani yang menggembala itikitiknya disawah. Pada pertengahan bulan Februari - Juni dan pertengahan bulan Agustus - Desember, wisatawan akan dapat menikmati atraksi pembibitan padi, aktivitas menanam padi dan pemeliharaannya hingga proses pemanenan.

Tabel 1. Jadwal Tanam Padi Sawah Desa Belimbing

\begin{tabular}{|c|c|c|c|c|c|c|c|c|c|c|c|}
\hline Jan & Feb & Mar & Apr & Mei & Jun & Jul & Agst & Sept & Okt & Nov & Des \\
\hline $\begin{array}{c}\text { Masa } \\
\text { bera }\end{array}$ & $\begin{array}{c}\text { Masa olah } \\
\text { tanah - } \\
\text { pembibitan }\end{array}$ & $\begin{array}{c}\text { Masa tanam - } \\
\text { panen }\end{array}$ & $\begin{array}{c}\text { Masa } \\
\text { bera }\end{array}$ & $\begin{array}{c}\text { Masa olah } \\
\text { tanah - } \\
\text { pembibitan }\end{array}$ & $\begin{array}{c}\text { Masa tanam - } \\
\text { panen }\end{array}$ \\
\hline
\end{tabular}

Topografi wilayah Desa Belimbing memiliki karakteristik berupa daerah perbukitan dan pegunungan karena terletak di kaki Gunung Batukaru (2.276 m), dan juga merupakan daerah aliran sungai. Ditinjau dari kemiringan lahan, sebagian besar lahan di Desa Belimbing berada pada kemiringan lereng 15 - 40\% (agak curam-curam) (Tabanan Dalam Angka, 2009). 
Namun kondisi topografi yang berbukit-bukit dan lahannya berada pada kemiringan yang cukup curam, hal ini memberikan keuntungan bagi Desa Belimbing, karena topografi yang berbukit-bukit tersebut memberikan pemandangan yang unik bagi wisatawan. Dan dengan kondisi topografi yang demikian, lahan persawahan dibentuk berundag-undag sehingga menjadikan lahan persawahan yang ada memiliki nilai estetika yang dapat menjadi daya tarik bagi wisatawan. Kondisi topografi Desa Belimbing dapat dilihat pada Gambar 2. Topografi atau bentuk permukaan bumi merupakan sumberdaya estetika dan visual yang berpengaruh terhadap lokasi dari penggunaan lahan serta fungsi rekreasi interpretatif dan lainnya.
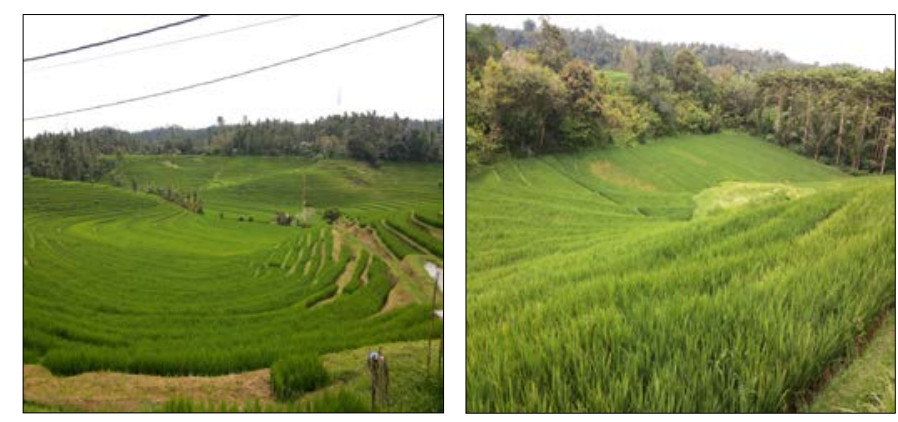

Gambar 2. Kondisi Topografi Desa Belimbing

Tingkat pendidikan warga di Desa Belimbing beraneka ragam. Sebagian besar warganya merupakan lulusan Sekolah Dasar (SD), yaitu sebanyak 1.945 jiwa atau sekitar 43\% dari jumlah penduduk 4.521 jiwa. Untuk tamatan Sekolah Menengah Pertama (SMP) sebanyak 1.104 jiwa atau sekitar 24\% dari total jumlah penduduk. Sedangkan untuk tamatan Sekolah Menengah Atas (SMA) sebanyak 708 jiwa, tamatan Diploma 17 jiwa, tamatan Sarjana (S1) 60 jiwa, dan S2 1 jiwa. Karena tingkat pendidikan masyarakatnya masih rendah, masyarakat setempat perlu diedukasi agar dapat mendukung kegiatan ekowisata.

Dari total jumlah penduduk 4.521 jiwa, sebanyak 2.889 jiwa atau sekitar 63\% bermata pencaharian sebagai petani. Apabila kawasan subak setempat dikembangkan sebagai ekowisata, hal tersebut dapat menguntungkan sebagian besar masyarakatnya yang berprofesi sebagai petani. Karena, dengan adanya kegiatan pariwisata yang melibatkan subak, sudah seharusnya mereka merasakan imbasnya dan kesejahteraan petani dapat meningkat. Dengan meningkatnya kesejahteraan petani karena tambahan penghasilan dari sektor pariwisata, maka diharapkan petani akan lebih giat bekerja dan mempertahankan sawah mereka karena dari kegiatan mereka bertani, mereka mendapatkan penghasilan tambahan. Sehingga, dengan demikian keinginan mereka untuk menjual tanah sawah mereka dapat ditekan dan eksistensi subak dapat terjaga.

Desa Belimbing memiliki jumlah subak yang paling banyak jika dibandingkan dengan desa-desa lainnya yang ada di Kecamatan Pupuan. Di Desa Belimbing terdapat tujuh subak yang terdiri dari enam subak basah dan satu subak abian (Kecamatan Pupuan Dalam Angka, 2014). Subak basah yang terdapat di Desa Belimbing yaitu; Subak Gemuh, 
Subak Mas, Subak Teben Telabah, Subak Duren Taluh, Subak Suradadi, dan Subak Nyanglad. Sedangkan, untuk subak abian hanya terdapat satu subak, yaitu Subak Swarna Pala. Organisasi subak yang ada di Desa Belimbing merupakan organisasi subak yang masih aktif, sehingga kegiatan-kegiatan yang terkait subak masih rutin dilakukan. Kegiatan-kegiatan tersebut antara lain musyawarah, gotong-royong, saling membagi air, dan kegiatan-kegiatan keagaaman yang berkaitan dengan aktivitas pertanian. Kegiatankegiatan yang masih dilakukan subak ini dapat menjadi atraksi wisata. Wisatawan juga dapat mempelajari nilai-nilai yang terkandung di dalamnya.

Berdasarkan persepsi masyarakat dan hasil observasi lapang, pengembangan ekowisata di kawasan subak yang berada di Desa Belimbing sudah memenuhi syarat untuk dikembangkan menjadi daya tarik ekowisata karena telah memenuhi unsur 6A yaitu Attraction, Accessibility, Amenities, Available, Activities, dan Ancillary Services. Potensipotensi kawasan subak yang memenuhi unsur $6 \mathrm{~A}$, yaitu sebagai berikut:

a. Attraction/atraksi: potensi atraksi di Desa Belimbing yang dapat dinikmati oleh wisatawan antara lain: sumber daya alamnya berupa hamparan persawahan dengan sistem terasering yang indah, perkebunan, bentang alam, sungai dan air terjun yang masih alami, dan Suaka Marga Satwa Mekori. Atraksi dari aspek sosial budaya yang berpotensi menarik wisatawan antara lain: kegiatan-kegiatan kelompok subak (musyawarah, gotong royong, dan ritual keagamaan), kehidupan sehari-hari warga setempat dengan adat istiadat setempat, tempat-tempat suci, dan kegiatan keagamaan lainnya. Sumber daya manusia yang sedang berkegiatan pertanian di Desa Belimbing juga berpotensi menjadi atraksi yang ditawarkan kepada para wisatawan. Petani yang sedang bekerja di sawah, kelompok-kelompok(sekaa) kesenian yang ada di Desa Belimbing, dan masyarakat yang berprofesi sebagai perajin dapat menjadi bagian dari atraksi wisata.

b. Accessibility/Aksesibilitas: akses untuk menuju Desa Belimbing dan akses untuk kegiatan ekowisata yang ada dalam kondisi yang baik. Akses yang ada sudah dapat mendukung kegiatan-kegiatan ekowisata diselenggarakan di Desa Belimbing. Jalurjalur yang menunjang untuk kegiatan trekking dan cycling juga sudah ada, namun kondisinya masih perlu perbaikan demi keamanan dan kenyamanan wisatawan. Beberapa jalur yang digunakan untuk aktifitas pariwisata merupakan jalan usaha tani yang dibangun swadaya oleh kelompok subak. Untuk mencapai Desa Belimbing, sarana transportasi yang digunakan dapat berupa angkutan umum antar propinsi dan juga segala jenis angkutan pribadi.

c. Amenities/Fasilitas: sebagai syarat untuk memenuhi kebutuhan wisatawan akan kenyamanan, fasilitas umum sangat dibutuhkan oleh sebuah objek wisata. Di Desa Belimbing, beberapa fasilitas umum telah dibangun untuk memenuhi kebutuhan masyarakat maupun wisatawan. Fasilitas toilet umum merupakan hal krusial yang harus dimiliki sebuah objek wisata. Di Desa Belimbing, toilet umum hanya tersedia di sebelah wantilan desa yang berdekatan dengan pasar. Kondisi toilet umum tersebut masih perlu perhatian pengelola pariwisata setempat agar layak untuk wisatawan yang berkunjung. Dan sepanjang jalur trekking/cycling, belum tersedia 
toilet umum, sehingga wisatawan harus meminjam toilet yang ada di rumah warga yang dilalui. Fasilitas listrik yang ada sudah cukup memadai. Jaringan listrik yang dibangun oleh PLN dapat dinikmati oleh masyarakat untuk kepentingan rumah tangga maupun industry rumahan (home industry). Fasilitas penerangan jalan merupakan hasil swadaya masyarakat, baik yang berada di ruas jalan propinsi maupun jalan dusun. Kondisinya belum memadai untuk menerangi wilayah Belimbing secara optimal, terutama pada malam hari. Fasilitas air bersih sudah tersedia, dari hasil swadaya masyarakat dan PDAM dengan sumber air dari mata air setempat. Fasilitas jaringan telepon kabel hingga saat ini belum menjangkau Desa Belimbing. Mayoritas masyarakat menggunakan telepon seluler untuk kepentingan komunikasi. Fasilitas penginapan dan tempat makan sudah tersedia di Desa Belimbing. Beberapa vila dan restoran telah dibangun investor untuk menunjang kegiatan pariwisata di Desa Belimbing. Selanjutnya, masyarakat diharapkan mampu menyediakan fasilitas penginapan bagi wisatawan. Pondok wisata (home stay) milik masyarakat dapat dimanfaatkan sekaligus untuk mengontrol kegiatan pariwisata secara langsung, dan mendapatkan manfaatnya secara langsung juga.

d. Available packages/ Paket yang tersedia; paket wisata yang disediakan Desa Belimbing termasuk spesifik, karena atraksi wisata yang ada mayoritas berbasis pada alam. Jika atraksi wisata alam ini dapat dikombinasikan dengan atraksi budaya yang dimiliki Belimbing, maka Desa Belimbing sangat berpotensi untuk dikembangkan sebagai objek ekowisata. Wisatawan yang berkunjung ke Belimbing dapat menikmati hamparan sawah berteras yang indah dan juga dapat berinteraksi langsung dengan petani di sawah atau dikebunnya sambil mengabadikan momen tersebut dengan memotretnya. Selain menikmati keindahan alam, wisatawan juga dapat menyaksikan kegiatan keagamaan yang terkait dengan aktivitas masyarakat. Penyebaran informasi mengenai potensi Desa Belimbing ini perlu lebih diperhatikan lagi, agar potensi-potensi yang ada dapat menjadi lebih berkembang. Namun, pengembangan yang dilakukan harus ditekankan dengan tujuan konservasi untuk potensi ekologis dan sosial budaya yang ada.

e. Activities/Aktivitas: aktivitas yang dapat dilakukan wisatawan jika berkunjung ke Desa Belimbing adalah kegiatan trekking yang sudah mulai dirintis masyarakat setempat. Namun, masyarakat setempat belum dapat menjadikan aktivitas trekking ini sebagai mata pencaharian utama karena terkendala pengetahuan dan bahasa. Hanya segelintir masyarakat yang menjadi guide atau penunjuk jalan jika ada wisatawan yang berkunjung. Kebanyakan wisatawan yang datang sudah diantar oleh pramuwisatanya. Aktivitas trekking ini dapat memberikan pengalaman baru bagi wisatawan. Peserta trekking akan diajak menelusuri jalur trekking yang melewati perkampungan penduduk sehingga wisatawan dapat berinteraksi dengan masyarakat setempat dan mengamati kegiatan sehari-hari mereka. Wisatawan juga diajak melintasi perkebunan dan persawahan, sehingga wisatawan dapat memperhatikan apa yang sedang dikerjakan oleh petani di sawah/di kebunnya. Setelah itu, wisatawan diajak melihat air terjun Singsing Sade dan Singsing Benben. 
Sepanjang perjalanan, wisatawan dapat mendokumentasikan apa yang mereka lihat selama perjalanan. Pramuwisata akan menjelaskan mengenai topografi desa, kondisi alam setempat, kegiatan di sawah tentang budidaya padi mulai dari pengolahan tanah - masa panen dan nilai gotongroyongnya yang masih sangat kental, kegiatan kelompok subak sebagai fungsi utama pengairan sawah, kegiatan perkebunan terutamanya kopi, kegiatan-kegiatan keagamaan masyarakat terkait kesehariannya (way of life) dan sejarah adanya Suaka Marga Satwa Mekori. Selain aktivitas trekking, wisatawan juga dapat melakukan aktivitas cycling mengelilingi desa mengikuti jalur yang sudah ada dengan mengendarai sepeda. Atraksi yang dapat dinikmati sama dengan jika melakukan aktivitas trekking. Jika bersepeda, wisatawan tidak dapat mengeksplorasi alam Belimbing secara bebas karena keterbatasan sarana (sepeda) dengan medan yang ada.

f. Ancillary services/Pelayanan tambahan: masyarakat lokal harus dilibatkan dalam pengelolaan untuk mengembangkan kawasan Subak Desa Belimbing sebagai ekowisata. Tujuan yang ingin dicapai dari implementasi konsep ekowisata adalah kelestarian alam dan budaya serta tercapainya kesejahteraan masyarakat. Agar pengembangan potensi yang ada dapat optimal, pengelolaan ekowisata ini haruslah profesional dan mampu menyediakan interpretasi sehingga wisatawan berpeluang untuk menikmati dan meningkatkan rasa cintanya terhadap alam. Masyarakat setempat yang tingkat pendidikannya masih rendah, harus diberikan pemahaman mengenai kegiatan pariwisata, sehingga dapat memberikan pelayanan yang memuaskan bagi wisatawan yang berkunjung.

\section{Simpulan}

Berdasarkan hasil penelitian studi potensi kawasan subak sebagai ekowisata di Desa Belimbing, dapat disimpulkan bahwa:

1. Potensi-potensi yang ada di kawasan subak Desa Belimbing yaitu:

a. Pemandangan sawah berteras yang indah.

b. Atraksi-atraksi wisata yang berasal dari kegiatan-kegiatan subak.

c. Kondisi iklim pada tapak yang sejuk.

d. Kearifan lokal yang masih dipegang teguh masyarakat setempat.

e. Aksesibilitas yang menunjang kegiatan ekowisata.

2. Potensi-potensi yang dimiliki subak di Desa Belimbing dapat dikembangkan sebagai ekowisata, karena kawasan subak setempat sudah memiliki daya tarik berupa sawah berterasnya yang indah, kegiatan perkebunannya dapat menjadi atraksi wisata, paket kegiatan outdoor berupa trekking dan cycling sudah tersedia, akomodasi penunjang wisata sudah ada, nilai-nilai sosial budaya setempat masih terjaga keasliannya, dan utamanya kegiatan-kegiatan subak yang dapat menjadi atraksi wisata masih rutin dilakukan.

3. Tingkat pendidikan SDM yang rendah, berpotensi menjadi kendala dalam pengembangan kawasan subak sebagai ekowisata. Maka dari itu SDM yang ada di Desa Belimbing masih perlu diedukasi agar dapat mendukung pengembangan kawasan subak sebagai ekowisata. 


\section{Daftar Pustaka}

BPS. 2010. Sensus Penduduk: Sketsa Peta. Badan Pusat Statistik Kabupaten Tabanan.

BPS. 2014. Bali dalam Angka, Badan Pusat Statistik Provinsi Bali.

BPS. 2014. Kecamatan Pupuan dalam Angka, Badan Pusat Statistik Kabupaten Tabanan. BPS. 2015. Bali dalam Angka, Badan Pusat Statistik Provinsi Bali.

Buhalis, D. 2000. Tourism Management: Marketing The Competitive Destination of The Future. University of Westminster. 